\title{
KARAKTERISTIK FISIKOKIMIA DAN FUNGSIONAL TEKNIS TEPUNG KORO KRATOK (Phaseolus lunatus L.) TERMODIFIKASI YANG DIPRODUKSI SECARA FERMENTASI SPONTAN
}

\author{
Ahmad Nafi', Nurud Diniyah, Febriani Tri Hastuti \\ Jurusan Teknologi Hasil Pertanian, Fakultas Teknologi Pertanian, Universitas Jember \\ Korespondensi : Jln. Kalimantan 37, Kampus Tegal Boto Jember 68121 \\ E-mail: ama_nafi'@yahoo.com
}

\begin{abstract}
Lima bean (Phaseolus lunatus L.) has a high bioavailability and good of amino acids balanced. Lima bean was pontentially used as a food ingredient on food manufacturing. In order to enhance its properties, the bean flour wasmodified by spontaneous fermentation. The aim of this research was to obtaine the appropriate fermentation $\mathrm{pH}$ and time on the production of modified lima bean flour. The fermentation $p H$ were 4.5; 5 and 5.5 in combination with fermentation time of 16, 24 and 32 hour. The Modified lima bean flour was then determined its moisture, ash, fat and soluble protein content. viscosity, bulk density, lightening, oil holding capacity $(\mathrm{OHC})$, water holding capacity (WHC), foaming activity and stability index, emulsifing activity and stability index. The research results showed that the best treatment resulted by fermentation $\mathrm{pH}$ of 5.5 for 16 hours. The modified lima bean flour had $8.10 \pm 0.68 \%$ water content, $5.52 \pm 1.06 \%$ ash content, $0.19 \pm 2.18 \%$ fat content, $33.74 \pm 1.20$ $\%$ soluble protein content, $16 \pm 0.00 \mathrm{mPas}$, hot viscosity, $17.33 \pm 0.58 \mathrm{mPas}$ cold viscosity, 0.88 $\pm 0.00 \mathrm{~g} / \mathrm{ml}$ bulk density, $91.43 \pm 0.38$ brightness, $250.01 \pm 43.76 \%$ oil holding capacity (OHC), $189.49 \pm 9.17 \%$ water holding capacity $(W H C), 28.22 \pm 0.40 \mathrm{ml} / \mathrm{g}$ foaming activity, $26.52 \pm$ $1.31 \%$ foaming stability, $333.63 \pm 6.70 \mathrm{~m} 2 / \mathrm{g}$ emulsion activity and $3.66 \pm 0.01$ hour emulsion stability. Based on those properties, the modified lima bean flour showeh high potency on many food application.
\end{abstract}

Key word : fermentation, modified flour, functional, lima bean, physicochemical.

\section{PENDAHULUAN}

Indonesia merupakan salah satu negara yang kaya akan tanaman polongpolongan, salah satunya adalah koro kratok (Phaseolus lunatus L). Tanaman koro-koroan mudah dibudidayakan dan memiliki produktivitas biji kering yang cukup tinggi sekitar $800-900 \mathrm{~kg} / \mathrm{ha}$ pada lahan kering dan kurang lebih $1700 \mathrm{~kg} / \mathrm{ha}$ apabila lahan diberi pengairan (Suhardi, 1989). Selama ini pemanfaatan koro kratok masih rendah, biasanya hanya digunakan untuk sayur, padahal kandungan proteinnya untuk setiap 100 gram bagian yang dapat dimakan adalah polong muda 1,3 gram; biji muda 8,4 gram dan daun segar 0,6 gram. Koro kratok (Phaseolus lunatus L) memiliki potensi yang sangat besar menjadi produk pangan apabila ditinjau dari segi gizi dan syarat tumbuhnya. Dari kandungan gizi, koro kratok memiliki semua unsur gizi dengan nilai gizi yang cukup tinggi, yaitu karbohidrat $54,5-74,2 \%$, protein 17,9 - 29\%, dan serat 3,5 - 11\% (Salunkhe dan Kadam, 1989). Melihat kandungan gizinya yang lengkap, sangat disayangkan bahwa koro kratok belum banyak dimanfaatkan oleh masyarakat.

Permasalahan yang dihadapi dalam pemanfaatan koro kratok adalah adanya beberapa senyawa anti gizi dan racun, antara lain asam sianida ( $\mathrm{HCN})$, anti tripsin (trypsin inhibitor), dan asam fitat. Keberadaan senyawa - senyawa tersebut dapat menimbulkan rasa pahit dan gangguan kesehatan apabila proses pengolahannya tidak tepat. Oleh karena itu diperlukan beberapa perlakuan untuk mengurangi kandungan senyawa anti gizi dan racun dalam koro kratok untuk menjadi produk pangan yang aman untuk dikonsumsi. Salah satu proses yang dapat dilakukan untuk mengurangi kandungan senyawa anti gizi dan racun, serta 
memperbaiki sifat organoleptik yaitu dengan cara fermentasi.

Fermentasi koro-koroan atau bijibijian baik secara alami atau spontan maupun menggunakan kultur murni seperti bakteri asam laktat (BAL) mampu mengurangi resiko defisiensi energi dan mikronutrien, menurunkan kandungan senyawa antigizi, meningkatkan protein terlarut (Antony dan Chandra, 1998) sehingga rasa, aroma, tekstur dan daya simpannya lebih baik dari bahan asalnya. Menurut Kinsella dan Shetty (1985), pemanfaatan protein menjadi bahan tambah dalam produk pangan olahan harus memiliki sifat-sifat fungsional yang baik. Pangan olahan memerlukan bahan baku dengan spesifikasi tertentu, sehingga koro kratok yang terfermentasi dilakukan penepungan agar dapat diaplikasikan sebagai bahan tambahan makanan (BTM) pada pangan olahan.

Tepung koro kratok termodifikasi memiliki sifat fungsional teknis yang baik, meliputi daya serap air, daya serap minyak, aktivitas emulsi dan stabilitas emulsi sehingga dapat digunakan sebagai food ingredient baru pada pangan olahan seperti, sosis, cake, cookies, dan nugget. Berdasarkan penelitian sebelumnya yang dilakukan oleh Fitrianingtyas (2013), menyatakan bahwa tepung koro komak yang difermentasi secara spontan dengan perlakuan fermentasi selama 24 jam pada $\mathrm{pH} 5$ memiliki sifat fungsional teknis yang baik meliputi daya serap air sebesar $160 \%$ dan daya serap minyak sebesar $180 \%$. Sifat fisik, kimia dan fungsional teknis tepung koro kratok termodifikasi sangat dipengaruhi oleh $\mathrm{pH}$ dan waktu fermentasi. Untuk itu perlu dilakukan penelitian tentang pengaruh $\mathrm{pH}$ dan waktu fermentasi pada produk tepung koro kratok termodifikasi yang dapat menghasilkan tepung koro kratok termodifikasi terbaik.

Tujuan penelitian ini untuk memperoleh $\mathrm{pH}$ dan lama fermentasi yang tepat sehingga dihasilkan tepung koro kratok termodifikasi dengan sifat-sifat baik. $\mathrm{pH}$ yang digunakan 4,$5 ; 5$ dan 5,5 dengan lama fermentasi 16, 24 dan 32 jam.

\section{METODE PENELITIAN}

\section{Bahan dan Alat}

Bahan yang digunakan yaitu koro kratok yang diperoleh dari daerah Cerme, Bondowoso, aquades, natrium klorida $(\mathrm{NaCl})$, asam sitrat, petroleum benzene, larutan Bovine Serum Albumin (BSA), reagen mixLowry, reagen Follin ciocalteu, buffer phosphate $0,05 \mathrm{M} \mathrm{pH} \mathrm{7,} \mathrm{minyak} \mathrm{sawit,} \mathrm{larutan}$ SDS $0,1 \%$. Alat yang digunakan yaitu soxhlet, neraca analitik, viskotester, tanur, pipet mikro, sentrifuge Yenaco model YC1180 dan tabungnya, spektrofotometer, Colour Reader merek Minolta (CR-10) dan alat-alat gelas.

\section{Rancangan Penelitian}

Penelitian dilakukan dengan menggunakan Rancangan Acak Kelompok faktorial (RAKF) dengan dua faktor yang masing-masing kombinasi diulang tiga kali Perlakuan $\mathrm{A}$ adalah $\mathrm{pH}$ yaitu : $\mathrm{A} 1=\mathrm{pH} 4,5$; $\mathrm{A} 2=\mathrm{pH} 5$ dan $\mathrm{A} 3=\mathrm{pH}$ 5,5. Perlakuan $\mathrm{B}$ adalah waktu fermentasi yaitu : $\mathrm{B} 1=16 \mathrm{jam}$, $\mathrm{B} 2=24 \mathrm{jam}$, dan B3 = 32 jam. Dari kedua perlakuan tersebut diperoleh kombinasi perlakuan yaitu A1B1; A1B2; A1B3; A2B1; A2B2; A2B3; A3B1; A3B2 dan A3B3. Pengolahan data penelitian menggunakan ANOVA dengan hasil yang ditampilkan dalam bentuk tabel dan grafik. Jika terdapat hasil data yang berbeda nyata dilakukan uji lanjut menggunakan DMRT (Duncan Multiple Range Test) untuk data sifat fisik, kimia, dan fungsional teknis pada taraf pengujian $1 \%$ dan $5 \%$. Serta menggunakan uji efektivitas untuk menentukkan perlakuan yang terbaik.

\section{Pembuatan Tepung Koro Kratok Termodifikasi}

Penelitian dilakukan dengan

fermentasi koro kratok dan penepungan koro kratok. Pembuatan tepung koro kratok termodifikasi dengan cara bahan baku koro kratok yang diretakkan lalu direndam dalam larutan asam sitrat dengan perbandingan (1:3) dan variasi $\mathrm{pH}(4,5 ; 5$ dan 5,5$)$ serta lama fermentasi (16 jam, 24 jam dan 32 jam) kemudian dilakukan pencucian sebanyak 2 kali. 
Tabel 1. Komposisi kimia tepung koro kratok termodifikasi

\begin{tabular}{ccccc}
\hline Perlakuan & Kadar air $(\%)$ & Kadar abu $(\%)$ & Kadar lemak $(\%)$ & Kadar protein terlarut $(\%)$ \\
\hline A1B1 & $8,10 \pm 0,68$ & $4,82 \pm 0,66$ & $2,08 \pm 0,12$ & $32.98 \pm 2,23$ \\
A2B1 & $8,11 \pm 0,73$ & $4,60 \pm 1,55$ & $1,99 \pm 0,05$ & $33.07 \pm 0,85$ \\
A3B1 & $8,13 \pm 0,63$ & $4,70 \pm 1,23$ & $1,88 \pm 0,06$ & $33.74 \pm 1,20$ \\
A1B2 & $8,23 \pm 0,57$ & $3,82 \pm 0,58$ & $2,16 \pm 0,13$ & $31.79 \pm 0,67$ \\
A2B2 & $8,25 \pm 0,68$ & $3,50 \pm 0,83$ & $1,98 \pm 0,04$ & $32.21 \pm 0,85$ \\
A3B2 & $8,32 \pm 0,63$ & $4,05 \pm 0,98$ & $1,98 \pm 0,04$ & $32.28 \pm 0,42$ \\
A1B3 & $9,15 \pm 0,17$ & $5,07 \pm 0,55$ & $1,87 \pm 0,11$ & $30.76 \pm 1,39$ \\
A2B3 & $8,94 \pm 0,73$ & $4,77 \pm 0,97$ & $2,05 \pm 0,13$ & $30.74 \pm 1,10$ \\
A3B3 & $9,16 \pm 0,55$ & $5,52 \pm 1,06$ & $2,18 \pm 0,19$ & $30.96 \pm 1,55$ \\
\hline
\end{tabular}

Selanjutnya dilakukan perendaman dalam larutan $\mathrm{NaCl} \quad 10 \%$ dengan perbandingan (1:3) selama 15 menit, kemudian dicuci dan ditiriskan. Selanjutnya digiling dan dikengeringkan menggunakan oven pada suhu $60 \mathrm{oC}$ selama 24 jam, setelah kering digiling dan dilanjutkan pengayakan menggunakan ayakan 70 mesh.

\section{Analisis}

Tepung koro kratok termodifikasi dianalisis proksimat meliputi : kadar air (Sudarmadji et. al., 1997), kadar abu (Sudarmadji et. al., 1997), kadar lemak (Sudarmadji et. al., 1997) dan kadar protein terlarut metode Lowry (Parkington et. al., 2000). Sifat fisik meliputi : viskositas (Subagio, 2006), densitas kamba (Santika, 2012) dan kecerahan (Subagio, 2006). Karakterisasi sifat fungsional meliputi : Oil Holding Capacity (OHC) (Subagio et. al., 2003), Water Holding Capacity (WHC) (Subagio et. al., 2003), daya buih dan stabilitas (Subagio et. al., 2003), serta daya emulsi dan stabilitas (Parkington et. al., 2000). Penentuan perlakuan terbaik menggunakan uji efektivitas (De Garmo et al., 1994).

\section{HASIL PENELITIAN}

\section{Proksimat Tepung Koro Kratok Termodifikasi}

Analisis proksimat yang dilakukan yaitu meliputi : kadar air, abu, lemak dan protein terlarut. Kadar air yang dihasilkan berkisar antara 8,10 $\pm 0,68$ sampai 9,16 $\pm 0,55$ $\%$ dengan kadar abu yang berkisar antara 3,50 $\pm 0,83$ sampai $5,52 \pm 1,06 \%$ (dry basis) dan kadar lemak yang berkisar antara 1,88 $\pm 0,06$ sampai 2,18 $\pm 0,19 \%$ (dry basis), serta kadar protein terlarut yang berkisar antara $30.74 \pm$ 1,10 sampai $33.74 \pm 1,20 \%$ (dry basis). Hasil analisis proksimat tepung koro kratok termodifikasi dapat dilihat pada Tabel 1.

\section{Viskositas}

Viskositas tepung koro kratok termodifikasi pada suhu $90^{\circ} \mathrm{C}$ berada pada kisaran nilai $11,67 \pm 0,58$ sampai $16 \pm 0,00$ mPas. Viskositas tepung koro kratok termodifikasi berbagai variasi $\mathrm{pH}$ perendaman dan waktu fermentasi dapat dilihat pada Gambar 1. 


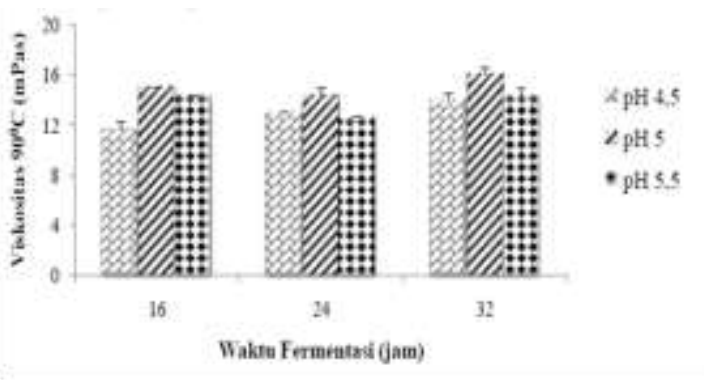

Gambar 1. Viskositas tepung koro kratok termodifikasi pada suhu $90 \mathrm{oC}$

Viskositas dingin tepung koro kratok termodifikasi pada suhu $27^{\circ} \mathrm{C}$ berada pada kisaran nilai $14,67 \pm 0,58$ sampai $17,33 \pm$ 0,58 mPas. Viskositas dingin tepung koro kratok termodifikasi dapat dilihat pada Gambar 2.

\section{Sifat Fisik Tepung Koro Kratok Termodifikasi}

Analisis sifat fisik tepung koro kratok termodifikasi meliputi densitas kamba dan kecerahan. Densitas kamba merupakan ukuran massa partikel yang menempati suatu unit volume tertentu. Densitas kamba tepung koro kratok termodifikasi berkisar antara 0,85 $\pm 0,01$ sampai $0,88 \pm 0,01 \mathrm{~g} / \mathrm{ml}$. Kecerahan dapat diketahui dengan menggunakan alat colour reader. Nilai kecerahan tepung koro kratok termodifikasi berkisar antara 90,01 \pm 1,73 sampai $91,43 \pm 0,38$. Hasil analisis sifat fisik tepung koro kratok termodifikasi dapat dilihat pada Tabel 2.

Tabel 2. Sifat fisik tepung koro kratok termodifikasi

\begin{tabular}{ccc}
\hline Perlakuan & Densitas $(\mathrm{g} / \mathrm{ml})$ & Kecerahan \\
\hline A1B1 & $0,87 \pm 0,01$ & $91,01 \pm 0,45$ \\
A2B1 & $0,85 \pm 0,01$ & $91,39 \pm 0,83$ \\
A3B1 & $0,88 \pm 0,01$ & $91,43 \pm 0,38$ \\
A1B2 & $0,87 \pm 0,00$ & $90,35 \pm 0,87$ \\
A2B2 & $0,86 \pm 0,01$ & $90,18 \pm 1,21$ \\
A3B2 & $0,87 \pm 0,01$ & $90,68 \pm 0,67$ \\
A1B3 & $0,86 \pm 0,01$ & $90,08 \pm 0,93$ \\
A2B3 & $0,86 \pm 0,01$ & $90,01 \pm 1,73$ \\
A3B3 & $0,88 \pm 0,01$ & $90,50 \pm 0,20$ \\
\hline
\end{tabular}

\section{Oil Holding Capacity (OHC) dan Water Holding Capacity (WHC)}

OHC merupakan kemampuan protein dalam kapasitas menyerap dan

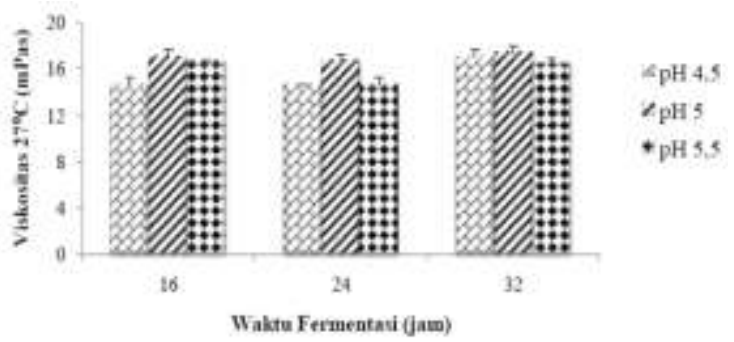

Gambar 2. Viskositas tepung koro kratok termodifikasi pada suhu $27^{\circ} \mathrm{C}$

menahan minyak tanpa kondisi pemanasan, sedangkan WHC kemampuan protein dalam kapasitas menyerap dan menahan air tanpa kondisi pemanasan. OHC yang dhasilkan berkisar antara 184,02 \pm 43,38 sampai 250,01 $\pm 43,76 \%$. Nilai WHC yang dhasilkan berkisar antara 168,19 \pm 17,67 sampai 189,49 $\pm 9,17 \%$. Hasil analisis OHC WHC tepung koro kratok termodifikasi dapat dilihat pada Tabel 3.

Tabel 3. OHC dan WHC tepung koro kratok termodifikasi

\begin{tabular}{ccl}
\hline Perlakuan & OHC $(\%)$ & \multicolumn{1}{c}{ WHC $(\%)$} \\
\hline A1B1 & $184,02 \pm 43,38$ & $184,00 \pm 5,07$ \\
A2B1 & $225,62 \pm 43,24$ & $168,19 \pm 17,67$ \\
A3B1 & $213,85 \pm 10,53$ & $173,51 \pm 26,13$ \\
A1B2 & $250,01 \pm 43,76$ & $182,85 \pm 15,28$ \\
A2B2 & $213,39 \pm 44,95$ & $170,40 \pm 11,87$ \\
A3B2 & $216,67 \pm 22,47$ & $189,49 \pm 9,17$ \\
A1B3 & $224,97 \pm 50,31$ & $179,10 \pm 13,72$ \\
A2B3 & $215,52 \pm 41,19$ & $172,99 \pm 4,26$ \\
A3B3 & $206,03 \pm 38,64$ & $173,83 \pm 9,16$ \\
\hline
\end{tabular}

\section{Daya Buih dan Stabilitas}

Buih merupakan bentukan dari sistem dua fase yang mengandung udara atau gas sebagai media terdispersi dan cairan koloid sebagai media pendispersi, Daya buih yaitu kemampuan untuk membentuk dan menghasilkan buih dalam jumlah tertentu, sedangkan kemampuan untuk mempertahankan buih dalam waktu tertentu disebut stabilitas buih

Daya buih yang dhasilkan berkisar antara $18,82 \pm 0,44$ sampai $28,22 \pm 0,40 \mathrm{ml} / \mathrm{g}$. Stabilitas buih yang dhasilkan berkisar antara $13,37 \pm 0,89$ sampai $26,52 \pm 1,31 \%$. Hasil analisis daya buih dan stabilitas tepung koro 
kratok termodifikasi dapat dilihat pada Tabel 4.

Tabel 4. Daya buih dan stabilitas tepung koro kratok termodifikasi

\begin{tabular}{ccc}
\hline Perlakuan & Daya buih $(\mathrm{ml} / \mathrm{g})$ & $\begin{array}{c}\text { Stabilitas buih } \\
(\%)\end{array}$ \\
\hline A1B1 & $19,30 \pm 0,47$ & $14,33 \pm 1,03$ \\
A2B1 & $19,74 \pm 0,30$ & $16,24 \pm 0,74$ \\
A3B1 & $28,22 \pm 0,40$ & $26,52 \pm 1,31$ \\
A1B2 & $19,11 \pm 0,28$ & $14,65 \pm 0,63$ \\
A2B2 & $19,43 \pm 0,67$ & $18,79 \pm 1,05$ \\
A3B2 & $28,22 \pm 0,40$ & $25,76 \pm 1,31$ \\
A1B3 & $18,82 \pm 0,44$ & $13,37 \pm 0,89$ \\
A2B3 & $19,06 \pm 0,65$ & $15,81 \pm 0,74$ \\
A3B3 & $27,70 \pm 0,54$ & $25,76 \pm 1,31$ \\
\hline
\end{tabular}

Daya Emulsi dan Stabilitas

Emulsi adalah suatu dispersi atau suspensi cairan dalam cairan yang lain yang mana kedua molekul cairan tersebut tidak menyatu. Daya emulsi adalah kemampuan untuk membentuk emulsi dan mempertahankan stabilitas emulsi tersebut. Sedangkan stabilitas emulsi diartikan sebagai kemampuan suatu emulsi tetap stabil dan tidak berubah terhadap koalesen (pecahnya lapisan film akibat penggabungan agregat) dan flokulasi (terbentuknya agregat dari dua atau lebih droplet yang masing-masing masih berbentuk gelembung). Pengamatan daya emulsi dinyatakan dalam aktivitas emulsi (EAI) dan stabilitas emulsi (ESI). Aktivitas emulsi dinyatakan sebagai area interfacial (antar permukaan) maksimal per gram protein yang dapat distabilkan. Daya emulsi tepung koro kratok termodifikasi berada pada kisaran nilai $305,57 \pm 1,56$ sampai $333,63 \pm 6,70$ $\mathrm{m}^{2} / \mathrm{g}$. Stabilitas emulsi tepung koro kratok termodifikasi berada pada kisaran nilai 3,51 \pm 0,01 sampai 3,66 $\pm 0,01 \mathrm{jam}$. Hasil analisis daya emulsi dan stabilitas tepung koro kratok termodifikasi dapat dilihat pada Tabel 5 .

\section{Uji Efektivitas}

Uji efektivitas digunakan untuk mengetahui perlakuan yang memiliki nilai tertinggi atau terbaik untuk semua parameter yang dianalisis, sehingga dapat digunakan untuk membantu menentukan perlakuan terbaik. Nilai efektivitas yang diperoleh dapat dilihat pada Tabel 6
Tabel 5. Daya emulsi dan stabilitas tepung koro kratok termodifikasi

\begin{tabular}{ccc}
\hline Perlakuan & $\begin{array}{c}\text { Aktivitas emulsi } \\
\left(\mathrm{m}^{2} / \mathrm{g}\right)\end{array}$ & $\begin{array}{c}\text { Stabilitas emulsi } \\
(\mathrm{jam})\end{array}$ \\
\hline A1B1 & $333,63 \pm 6,70$ & $3,60 \pm 0,08$ \\
A2B1 & $321,99 \pm 1,27$ & $3,64 \pm 0,01$ \\
A3B1 & $313,50 \pm 1,62$ & $3,66 \pm 0,01$ \\
A1B2 & $326,05 \pm 4,29$ & $3,63 \pm 0,05$ \\
A2B2 & $319,67 \pm 0,97$ & $3,65 \pm 0,06$ \\
A3B2 & $306,32 \pm 1,63$ & $3,66 \pm 0,02$ \\
A1B3 & $317,71 \pm 1,86$ & $3,53 \pm 0,02$ \\
A2B3 & $319,60 \pm 1,53$ & $3,51 \pm 0,01$ \\
A3B3 & $305,57 \pm 1,56$ & $3,65 \pm 0,02$ \\
\hline
\end{tabular}

Tabel 6. Hasil uji efektivitas tepung koro kratok termodifikasi

\begin{tabular}{cc}
\hline Perlakuan & nilai \\
\hline A1B1 & 0.49 \\
A2B1 & 0.58 \\
A3B1 & 0.70 \\
A1B2 & 0.50 \\
A2B2 & 0.46 \\
A3B2 & 0.58 \\
A1B3 & 0.34 \\
A2B3 & 0.39 \\
A3B3 & 0.57 \\
\hline
\end{tabular}

\section{PEMBAHASAN}

\section{Proksimat Tepung Koro Kratok Termodifikasi}

Berdasarkan tabel 1 dapat diketahui bahwa kadar air tertinggi yaitu pada perlakuan pH 5,5 dan fermentasi selama 32 jam $(8,10 \pm$ $0,68 \%$ ), sedangkan kadar air terendah yaitu pada perlakuan $\mathrm{pH} 4,5$ dan fermentasi selama 16 jam ( 8,10 $\pm 0,68 \%)$. Berdasarkan hasil analisis sidik ragam menunjukkan bahwa pada taraf $(\alpha) 1 \%$ pengaruh waktu fermentasi berbeda sangat nyata, akan tetapi pengaruh $\mathrm{pH}$ dan interaksi dua perlakuan tersebut tidak berbeda nyata. Peningkatan kadar air selama proses fermentasi disebabkan karena semakin lama waktu fermentasi aktivitas mikroorganisme dalam merombak makromolekul semakin meningkat sehingga kadar air yang dihasilkan akan semakin tinggi. Menurut Fardiaz (1992), pada proses fermentasi terjadi perombakan glukosa menjadi karbondioksida $\left(\mathrm{CO}_{2}\right)$ dan air $\left(\mathrm{H}_{2} \mathrm{O}\right)$ sehingga akan meningkatkan kadar air pada bahan kering. 
Berdasarkan tabel 1 dapat diketahui bahwa kadar abu tertinggi yaitu pada perlakuan $\mathrm{pH} 5,5$ dan fermentasi selama 32 jam $(5,52 \pm 1,06 \%)$, sedangkan kadar abu terendah yaitu pada perlakuan $\mathrm{pH} 5$ dan fermentasi selama 24 jam ( $3,50 \pm 0,83 \%)$. Berdasarkan hasil analisis sidik ragam menunjukkan bahwa pada taraf $(\alpha) \quad 1 \%$ pengaruh waktu fermentasi berbeda sangat nyata, akan tetapi pengaruh $\mathrm{pH}$ dan interaksi dua perlakuan tersebut tidak berbeda nyata. Lama waktu fermentasi mempengaruhi kadar abu tepung koro kratok termodifikasi karena adanya mineral yang larut air saat pencucian dan perendaman selama fermentasi.

Berdasarkan tabel 1 dapat diketahui bahwa kadar lemak tertinggi yaitu pada perlakuan $\mathrm{pH}$ 5,5 dan fermentasi selama 32 jam $(2,18 \pm 0,19 \%)$, sedangkan kadar lemak terendah yaitu pada perlakuan $\mathrm{pH} 4,5$ dan fermentasi selama 32 jam $(1,88 \pm 0,06 \%)$. Berdasarkan hasil analisis sidik ragam menunjukkan bahwa pada taraf $(\alpha) \quad 1 \%$ pengaruh lama fermentasi dan $\mathrm{pH}$ tidak berbeda nyata, akan tetapi pengaruh interaksi dua perlakuan tersebut berbeda sangat nyata. Hal tersebut diduga karena pada saat proses fermentasi spontan dimungkinkan bakteri lipolitik dapat tumbuh. Bakteri lipolitik adalah bakteri yang memproduksi enzim lipase yaitu enzim yang mengkatalis hidrolisis lemak menjadi asam-asam lemak dan gliserol (Winarno, 1997). Gliserol memiliki sifat mudah larut dalam air, tidak berwarna dan tidak berbau sehingga kadar lemak dalam bahan semakin menurun (Lindsay, 1985).

Berdasarkan tabel 1 dapat diketahui bahwa kadar protein terlarut tertinggi yaitu pada perlakuan $\mathrm{pH} 5,5$ dan fermentasi selama 16 jam (33.74 $\pm 1,20 \%)$, sedangkan kadar protein terlarut terendah yaitu pada perlakuan pH 4,5 dan fermentasi selama 32 jam (30.74 \pm $1,10 \%)$. Berdasarkan hasil analisis sidik ragam menunjukkan bahwa pada taraf $(\alpha) 1 \%$ pengaruh lama waktu fermentasi berbeda sangat nyata, akan tetapi pengaruh $\mathrm{pH}$ dan interaksi dua perlakuan tersebut tidak berbeda nyata. Hal tersebut diduga karena pada saat proses fermentasi, protein koro kratok larut dalam air rendaman sehingga nilai protein terlarutnya juga semakin berkurang.

\section{Viskositas}

Berdasarkan gambar 1 dapat diketahui bahwa viskositas panas tertinggi yaitu pada perlakuan $\mathrm{pH} 5$ dan fermentasi selama 32 jam (16 $\pm 0,00 \mathrm{mPas})$, sedangkan viskositas panas terendah yaitu pada perlakuan $\mathrm{pH}$ 4,5 dan fermentasi selama 16 jam $(11,67 \pm 0,58 \mathrm{mPas})$. Berdasarkan hasil analisis sidik ragam menunjukkan bahwa pada taraf $(\alpha) \quad 1 \quad \%$ pengaruh lama waktu fermentasi, $\mathrm{pH}$ dan interaksi dua perlakuan tersebut berbeda sangat nyata. Hal ini disebabkan karena semakin lama waktu fermentasi, semakin banyak granula pati yang mengalami pembengkakan karena granula pati dapat menyerap air. Proses pemanasan dapat memutuskan ikatan hidrogen yang menghubungkan antara amilosa dan amilopektin pada pati, sehingga menyebabkan granula pati membengkak akibat terisi oleh air. Pada granula pati yang membengkak ini mengakibatkan sebagian amilosa dari pati keluar dari granula dan terlarut dengan air sehingga dapat membentuk pro gel.

Berdasarkan gambar 2 dapat diketahui bahwa viskositas dingin tertinggi yaitu pada perlakuan $\mathrm{pH} 5$ dan fermentasi selama 32 jam $(17,33 \pm 0,58 \mathrm{mPas})$, sedangkan viskositas dingin terendah yaitu pada perlakuan $\mathrm{pH} 4,5$ dan fermentasi selama 16 jam $(11,67 \pm 0,58 \mathrm{mPas})$. Berdasarkan hasil analisis sidik ragam menunjukkan bahwa pada taraf $(\alpha) \quad 1 \%$ pengaruh lama waktu fermentasi, $\mathrm{pH}$ dan interaksi dua perlakuan tersebut berbeda sangat nyata terhadap viskositas dingin tepung koro kratok termodifikasi yang dihasilkan. Nilai viskositas dingin pada tepung koro kratok termodifikasi lebih tinggi dibandingkan dengan viskositas panas. Hal ini disebabkan penurunan suhu setelah dilakukannya pemanasan dapat mengakibatkan ikatan hidrogen antara grup hidroksil rantai linier yang berdekatan sehingga dapat membentuk gel. Pembentukan gel merupakan salah satu bukti kemampuan molekul linier pati terlarut untuk berasosiasi (Pomeranz, 1991).

\section{Sifat Fisik Tepung Koro Kratok Termodifikasi}

Tabel 2 menunjukkan densitas kamba tertinggi yaitu pada perlakuan $\mathrm{pH} 5,5$ dan fermentasi selama 32 jam $(0,88 \pm 0,01 \mathrm{~g} / \mathrm{ml})$, 
sedangkan densitas kamba terendah yaitu pada perlakuan $\mathrm{pH} 5,5$ dan fermentasi selama 24 jam $(0,85 \pm 0,01 \mathrm{~g} / \mathrm{ml})$. Berdasarkan hasil analisis sidik ragam menunjukkan bahwa pada taraf $(\alpha) \quad 5 \quad \%$ pengaruh lama waktu fermentasi, $\mathrm{pH}$ dan interaksi dua perlakuan tersebut tidak berbeda nyata. Hal ini diduga karena pada proses pembuatan tepung koro kratok termodifikasi menggunakan ayakan yang sama yaitu 70 mesh sehingga ukuran partikel tepung yang dihasilkan seragam dan tidak berbeda nyata antar perlakuan karena perlakuan $\mathrm{pH}$ dan lama fermentasi tidak mempengaruhi densitas kamba.

Berdasarkan tabel 2 dapat diketahui nilai kecerahan tertinggi yaitu pada perlakuan pH 5,5 dan fermentasi selama 16 jam $(91,43 \pm$ 0,38 ), sedangkan nilai kecerahan terendah yaitu pada perlakuan $\mathrm{pH} 5,5$ dan fermentasi selama 32 jam $(90,01 \pm 1,73)$. Berdasarkan hasil analisis sidik ragam menunjukkan bahwa pada taraf $(\alpha) 5 \%$ pengaruh lama waktu fermentasi berbeda nyata, sedangkan pengaruh $\mathrm{pH}$ dan interaksi dua perlakuan tersebut tidak berbeda nyata. Hal ini diduga karena dipengaruhi sebagian besar pigmen dan polifenol yang berikatan dengan protein larut dalam air selama fermentasi sehingga sedikit kandungan pigmen dan polifenolnya dan dapat meningkatkan nilai kecerahan tepung koro kratok termodifikasi.

\section{Oil Holding Capacity (OHC) dan Water Holding Capacity (WHC)}

Berdasarkan tabel 3 dapat diketahui nilai $\mathrm{OHC}$ tertinggi yaitu pada perlakuan $\mathrm{pH}$ 4,5 dan fermentasi selama 24 jam $(250,01 \pm$ $43,76 \%$ ), sedangkan nilai $\mathrm{OHC}$ terendah yaitu pada perlakuan $\mathrm{pH} 4,5$ dan fermentasi selama 16 jam (184,02 $\pm 43,38 \%)$. Berdasarkan hasil analisis sidik ragam menunjukkan bahwa pada taraf $(\alpha) \quad 5 \quad \%$ pengaruh lama waktu fermentasi, $\mathrm{pH}$ dan interaksi dua perlakuan tersebut tidak berbeda nyata. Hal ini menunjukkan bahwa tepung koro kratok termodifikasi banyak memiliki protein dengan gugus hidrofobik. Penyerapan minyak selain terjadi karena minyak terperangkap secara fisik dalam protein tetapi juga terdapatnya ikatan non kovalen seperti atraksi hidrofobik, eletrostastik dan ikatan hidrogen pada interaksi lemak protein (Lawal, 2004). Hal ini diduga berhubungan dengan kandungan albumin pada tapung koro kratok termodifikasi (Subagio et. al., 2003).

Berdasarkan tabel 3 dapat diketahui Nilai WHC tertinggi yaitu pada perlakuan $\mathrm{pH}$ 5,5 dan fermentasi selama 24 jam $(189,49 \pm$ $9,17 \%$ ), sedangkan nilai WHC terendah yaitu pada perlakuan $\mathrm{pH} 5$ dan fermentasi selama 16 jam $(168,19 \pm 17,67 \%)$. Berdasarkan hasil analisis sidik ragam menunjukkan bahwa pada taraf $(\alpha) \quad 5 \quad \%$ pengaruh lama waktu fermentasi, $\mathrm{pH}$ dan interaksi dua perlakuan tersebut tidak berbeda nyata. Nilai WHC tepung koro kratok termodifikasi lebih rendah dibandingkan nilai OHC. Hal ini diduga dikarenakan gugus hidrofobik tepung koro kratok termodifikasi lebih dominan daripada gugus hidrofiliknya. Sehingga hidrofilisitas tepung koro kratok termodifikasi lebih rendah karena kelarutan proteinnya lebih tinggi. Hal ini sesuai dengan pernyataan El-Adawy (2000) bahwa protein dengan tingkat kelarutan yang tinggi mempunyai WHC yang rendah.

\section{Daya Buih dan Stabilitas}

Berdasarkan tabel 4 dapat diketahui daya buih tertinggi yaitu pada perlakuan $\mathrm{pH}$ 5,5 dan fermentasi selama 16 jam dan 24 jam $(28,22 \pm 0,40 \mathrm{ml} / \mathrm{g})$, sedangkan nilai daya buih terendah yaitu pada perlakuan $\mathrm{pH} 4,5$ dan fermentasi selama 32 jam $(18,82 \pm 0,44$ $\mathrm{ml} / \mathrm{g}$ ). Berdasarkan hasil analisis sidik ragam menunjukkan bahwa pada taraf $(\alpha) \quad 5 \%$ pengaruh $\mathrm{pH}$ dan lama waktu fermentasi berbeda nyata, sedangkan pengaruh interaksi dua perlakuan tersebut tidak berbeda nyata. Rendahnya $\mathrm{pH}$ mengakibatkan protein mengalami denaturasi sehingga kemampuan tepung koro kratok termodifikasi membentuk buih menurun karena kemampuan mengikat udara semakin rendah. Sifat pembuihan sangat dipengaruhi oleh $\mathrm{pH}$, suhu dan adanya komponen lain (Slack dan Hill, 1985). Rendahnya daya buih terjadi akibat nilai $\mathrm{pH}$ menyebabkan kondisi protein koro kratok terutama globulin akan pecah, sehingga akan menurunkan kemampuan untuk mengikat udara dalam proses pembentukan buih (Feed and Nagodawithana, 1991).

Berdasarkan tabel 4 dapat diketahui stabilitas buih tertinggi yaitu pada perlakuan 
pH 5,5 dan fermentasi selama 16 jam dan 32 jam $(26,52 \pm 1,31 \%)$, sedangkan nilai stabilitas buih terendah yaitu pada perlakuan pH 4,5 dan fermentasi selama 32 jam $(13,37 \pm$ $0,89 \%)$. Berdasarkan hasil analisis sidik ragam menunjukkan bahwa pada taraf $(\alpha) 5 \%$ pengaruh $\mathrm{pH}$ dan lama waktu fermentasi berbeda nyata, sedangkan pengaruh interaksi dua perlakuan tersebut tidak berbeda nyata. Semakin rendah $\mathrm{pH}$ maka semakin kecil stabilitas buih tepung koro kratok termodifikasi karena kemampuan mengikat dan mempertahankan udara semakin rendah.

\section{Daya Emulsi dan Stabilitas}

Berdasarkan tabel 5 dapat diketahui daya emulsi tertinggi yaitu pada perlakuan $\mathrm{pH}$ 4,5 dan fermentasi selama 16 jam $(333,63 \pm$ $6,70 \mathrm{~m} 2 / \mathrm{g}$ ), sedangkan nilai daya emulsi terendah yaitu pada perlakuan $\mathrm{pH} 5,5$ dan fermentasi selama 32 jam $(305,57 \pm 1,56$ $\mathrm{m} 2 / \mathrm{g}$ ). Berdasarkan hasil analisis sidik ragam menunjukkan bahwa pada taraf $(\alpha) \quad 1 \%$ pengaruh $\mathrm{pH}$, lama waktu fermentasi dan interaksi dua perlakuan tersebut berbeda sangat nyata. Hal ini diduga karena protein pada produk tepung koro kratok termodifikasi mengalami denaturasi yang menyebabkan meningkatnya jumlah gugus non polar dan ikatan silang antar protein sehingga kemampuan bahan untuk membentuk daya emulsi meningkat. Protein dengan jumlah hidrofobik tinggi akan diabsorbsi pada permukaan antar fase w/o dan protein akan menurunkan tegangan permukaan antar fase dan membentuk emulsi (Zayas, 1997).

Berdasarkan tabel 5 dapat diketahui stabilitas emulsi tertinggi yaitu pada perlakuan $\mathrm{pH} 5,5$ dan fermentasi selama 24 jam (3,66 $\pm 0,01$ jam), sedangkan nilai stabilitas emulsi terendah yaitu pada perlakuan $\mathrm{pH} 5$ dan fermentasi selama 32 jam $(3,51 \pm 0,01 \mathrm{jam})$. Berdasarkan hasil analisis sidik ragam menunjukkan bahwa pada taraf (a) $1 \%$ pengaruh $\mathrm{pH}$ dan lama waktu fermentasi berbeda sangat nyata, akan tetapi interaksi dua perlakuan tersebut tidak berbeda nyata. Nilai stabilitas emulsi berbanding terbalik dengan daya emulsi. Hal ini diduga karena gugus non polar lebih dominan sehingga emulsifier akan lebih kuat diikat oleh minyak dibandingkan air akibatnya tegangan permukaan lebih tinggi dan emulsi tidak mudah menyebar. Stabilitas emulsi penting karena pengemulsi yang baik tergantung pada kemampuan protein untuk memelihara sistem emulsi pada saat protein mengalami pemrosesan (Sugiyanto dan Manulang, 2001).

\section{Uji Efektivitas}

Berdasarkan data pada tabel 6, tepung koro kratok termodifikasi yang nilai efektivitas tertinggi yaitu pada perlakuan tepung $\mathrm{pH}$ 5,5 dan fermentasi selama 16 jam $(0,70)$, sedangkan nilai efektivitas terendah yaitu pada perlakuan tepung $\mathrm{pH} 4,5$ dan fermentasi selama 32 jam $(0,34)$. Sehingga dapat disimpulkan bahwa perlakuan terbaik yaitu tepung koro kratok termodifikasi perlakuan $\mathrm{pH}$ 5,5 dan fermentasi selama 16 jam. Hal ini didukung dengan hasil beberapa parameter pengamatan yang memiliki nilai terbaik, antara lain protein terlarut $(33.74 \pm$ $1,20 \%)$, kecerahan $(91,43 \pm 0,38)$, daya buih $(28,22 \pm 0,40 \mathrm{ml} / \mathrm{g})$, dan stabilitas buih $(26,52$ $\pm 1,31 \%)$.

\section{KESIMPULAN}

Perlakuan terbaik pada penelitian ini yaitu perlakuan $\mathrm{pH}$ 5,5 dan fermentasi selama 16 jam yaitu sebesar 0,70 dengan demikian tepung koro kratok termodifikasi lebih baik apabila digunakan dan diaplikasikan sebagai food ingredient baru sehingga menghasilkan produk yang lebih baik.

Nilai daya buih dan stabilitas buih tepung koro kratok termodifikasi cukup rendah sehingga diperlukan penelitian lebih lanjut untuk meningkatkan daya buih dan stabilitas buih tepung koro kratok termodifikasi.

\section{DAFTAR PUSTAKA}

Antony, H. dan T. S. Chandra. 1998. Antinutrient Reduction and Enhancement in Protein, Starch, and Mineral Availability in Fermented Flour of Finger Millet (Eleusine coracana). Agric. Food Chem 46 : 2578-2582.

Apriyantono, A., Fardiaz, D., dan Niluh, P. 1989. Analisis Pangan. Bogor : PAU Pangan dan Gizi IPB.

El-Adawy, T. A. 2000. Functional Properties and Nutritional Quality of Acetylated 
and Succinylated Mung Bean Protein Isolate. J. Food. Chem. $70: 83-91$.

Fardiaz, S. 1992. Mikrobiologi Pangan I. Jakarta : PT. Gramedia Pustaka Utama.

Feed, G. dan T. W. Nagodawithana. 1991. Yeast Technology. Second Edition. New York : Van Nostrand Reinhold.

Fitrianingtyas, A. 2013. "Karakteristik Tepung Koro Komak (Lablab purpureus (L.) Sweet) Termodifikasi Secara Fermentasi Spontan: Kajian pH dan Waktu". Tidak Diterbitkan. Skripsi. Jember : Jurusan Teknologi Hasil Pertanian Fakultas Teknologi Pertanian Universitas Jember.

Garmo, E. P., Sullevan, W. E., Canana. 1994. Engineering Economy. New York : Seventh edition.

Kinsella dan Shetty. 1985. ACS Symp. Dalam : Damodaran, S. 1997. Food Proteins and their Applycation. New York : Marcel Dekker. Inc.

Lawal, O. S. 2004. Functionality of African Locust Bean (parkia biglobossa) Protein Isolate : Effect of $\mathrm{pH}$, Ionic Strength and Various Protein Concentrations. J. Food. Chem. 86 : 345-355.

Parkingkton, Xiong, Blanchard, Srinivasan, dan Froning. 2000. Chemical and Functional Properties of Oxidatively Modified Beef Heart Surimi Stored at $2^{\text {nd }}$ C. Food Chermistry and Toxicology. Vol. 65 No. $3: 428-433$.

Pomeranz, Y. 1991. Functional Properties of Food Components. New York : Academic Press. 24-27.

Salunkhe, O. K., S. S. Kadam dan J. K. Chevan, 1985. Postharvest Biotecnology of Food Legume. Florida : CRC-Press Inc.

Slack, C. H. dan C. G. Hill. J. R. 1985. Journal of food processing and preservation. Vol. X.

Subagio, A. 2006. "Ubi Kayu : Substitusi Berbagai Tepung-Tepungan". Food. Review Indonesia. April 2006 : 18-22.

Subagio, A., W. S.Windrati, dan Y. Witono. 2003. Development of Functional Proteins From Some Local NonOilseed Legumes as Food Additives. Yogyakarta. Seminar Nasional
Perhimpunan Ahli Teknologi Pangan Indonesia.

Sudarmadji, S., Bambang Haryono dan Suhardi. 1997. Prosedur Analisa Untuk Bahan Makanan dan Pertanian. Yogyakarta : Liberty.

Sugiyanto dan A. M. Manulang. 2001. Pembuatan Protein Konsentrat Wheat Pollard Sebagai Pemanfaatan Hasil Samping Penggilingan Gandum. Jurnal Teknologi dan Industri Pangan Vol. XII No I: 54-56.

Suhardi. 1989. Kimia dan Teknologi Protein. Yogyakarta : Pusat Antar Universitas Pangan dan Gizi Universitas Gadjah Mada.

Winarno, F. G. 1997. Kimia Pangan dan Gizi. Jakarta : PT. Gramedia Pustaka Utama.

Zayas, J. F. 1997. Functionally of Protein in Food. Berlin : Springer 